\title{
Respons Beberapa Varietas Padi (Oryza sativa L.) terhadap Wereng Batang Coklat (Nilaparvata lugens Stall) Koloni Karawang
}

\author{
Dedi Darmadi' ${ }^{1}$, dan Tuti Alawiyah ${ }^{2}$ \\ ${ }^{1}$ Balai Besar Peramalan Organisme Pengganggu Tumbuhan Jatisari \\ 2Jurusan Agroteknologi, UIN Sunan Gunung Djati Bandung \\ Alamat korespondensi : dedibdg84@yahoo.com
}

\begin{abstract}
Response of rice varieties (Oryza sativa L.) to brown planthopper (Nilaparvata lugens Stall) of Karawang colonies
\end{abstract}

The research was conducted to determine the resistant level of several rice varieties (Oryza sativa L.) against brown planthopper (Nilaparvata lugens Stall) Karawang colony. The experiment was done at the Entomology Laboratory of Pest Forcesting Institute, Jatisari, Directorate General of Food Crops, Ministry of Agriculture. It was conducted from February to June 2017. The resistant of rice varieties against brown planthopper was tested using honey dew test method with bromocressol green as indicator. Honey dew test method is one of methods to evaluate rice variety reaction against brown planthopper population origin of certain area. This is due to the production of honey dew by brown planthopper which positively correlated with the amount of liquid being drawn from the plant. This study used Duncan Test on 5\% level. The result demonstrated the variation of rice resistant against brown planthopper based on the area of honey dew spot, brown planthover mortality, attacks intensity, the destruction level on plant, and the rice yield. Inpari 13 was the most toleranct rice variety against the infestation of brown planthopper of Karawang colony.

Keywords: Brown planthopper, Honey dew, Paddy, Resistance, Varieties

\begin{abstract}
ABSTRAK
Penelitian ini bertujuan untuk menilai tingkat ketahanan varietas padi (Oryza sativa L.) terhadap wereng batang coklat (Nilaparvata lugens Stall) koloni Karawang. Penilitian dilaksanakan di Laboratorium Entomologi Balai Besar Peramalan Organisme Pengganggu Tumbuhan (BBPOPT) Jatisari, Direktorat Jenderal Tanaman Pangan, Kementerian Pertanian. Penelitian berlangsung dari Bulan Februari sampai Bulan Juni 2017. Pengujian ketahanan varietas padi terhadap wereng batang coklat dilakukan dengan menggunakan metode uji embun madu (honeydew test) dengan memakai indicator bromocressol green. Metode uji embun madu merupakan salah satu metode untuk mengevaluasi reaksi suatu varietas terhadap populasi wereng batang coklat yang berkembang di suatu wilayah tertentu, karena jumlah embun madu yang dikeluarkan oleh wereng batang coklat mempunyai hubungan yang positif dengan jumlah cairan tanaman yang dihisap. Uji lanjut yang digunakan adalah uji lanjut Duncan pada taraf 5\%. Hasil penelitian menunjukkan terdapat variasi ketahanan antar varietas padi yang diuji dilihat dari luas bercak embun madu yang dihasilkan pada masing-masing varietas padi, mortalitas wereng batang coklat, intensitas serangan, tingkat kerusakan tanaman, dan bobot hasil panen padi. BErdasarkan parameter tersebut di atas, Inpari 33 merupakan varietas padi yang tahan terhadap serangan wereng batang coklat koloni Karawang.
\end{abstract}

Kata kunci : Embun madu, Ketahanan, Padi, Varietas, Wereng batang coklat 


\section{PENDAHULUAN}

Padi (Oryza sativa L.) merupakan salah satu komoditas pertanian yang penting dan menempati urutan pertama di Indonesia. Bahan pangan ini mengandung $8 \mathrm{~g}$ protein dan $73 \mathrm{~g}$ karbohidrat dalam setiap $100 \mathrm{~g}$ (Kastanja, 2011). Sebagai bahan pangan utama, kesinambungan produksi sangat dibutuhkan agar kualitas dan kuantitasnya tetap terjaga. Selain itu peningkatan teknologi, perbaikan varietas dan perbaikan teknik budidaya perlu dilakukan secara berkesinambungan agar produksi padi terus berlanjut.

Pemerintah Indonesia sejak tahun 1960 sampai sekarang selalu berupaya menjaga dan meningkatkan produksi padi. Berbagai upaya untuk menjaga stabilitas dan peningkatan produksi padi telah dilakukan oleh pemerintah Indonesia seperti intensifikasi, ekstensifikasi dan primatani. Programprogram tersebut telah dapat meningkatkan produksi padi di Indonesia (Sutrisno, 2014).

Kendala yang sering dihadapi oleh petani yaitu adanya organisme pengganggu tanaman (OPT). Salah satu pengganggu produksi tanaman padi diantaranya adalah hama tanaman, dimana hama ini menimbulkan gangguan pada tanaman padi secara fisik. Hama tanaman dapat berupa serangga, tungau atau moluska (Wiyono, 2007). Salah satu hama yang sering mengakibatkan gagal panen padi yaitu serangan Wereng Batang Coklat (WBC) (Ningsih dkk., 2016). Kerusakan yang ditimbulkan oleh WBC mampu mengakibatkan terjadinya gagal panen (Setyorini et al., 2013).

Setiap tahun WBC menyerang tanaman padi di beberapa tempat di Indonesia. Pada tahun 2010, serangan WBC yang diikuti penyakit virus kerdil hampa dan virus kerdil rumput menyebabkan penurunan produksi padi sebesar $1,1 \%$ pada tahun 2011 (65,756 juta ton gabah kering giling (GKG)) dari produksi tahun 2010 sebesar 66,469 juta ton GKG). Luas serangan WBC meningkat 5 kali lipat dari 47.473 ha pada tahun 2009 menjadi 218.060 ha pada tahun 2011 (Baehaki, 2012).

Berbagai metode telah dilakukan petani untuk mengendalikan hama tersebut baik secara fisik dan mekanik (Sjakoer, 2010). Selain itu dilakukan pengendalian biologis dengan memanfaatkan musuh alami. Pengendalian ini dianggap paling aman dan mampu menjaga keseimbangan ekosistem, namun hasil dari pengendalian tersebut baru dapat terlihat dalam jangka waktu yang lama (Syahrawati dkk., 2010).

Salah satu teknik pengendalian WBC yang efektif untuk digunakan adalah dengan menggunakan varietas tahan dan toleran. Data menunjukkan bahwa dengan aktivitas penelitian (termasuk pemuliaan tanaman) seperti saat ini, dalam waktu 15 tahun peningkatan hasil padi yang dapat diraih hanya $0,5 \mathrm{t} / \mathrm{ha}$, atau berarti memakan waktu 32 tahun untuk memenuhi kebutuhan pangan 21 tahun yang akan datang. Oleh karena itu diperlukan kajian mengenai status ketahanan varietas-varietas tanaman padi yang umum digunakan oleh para petani. Di Jawa Barat terdapat beberapa varietas padi yang ditanam oleh petani di lapangan di antaranya Pelita, Inpari 13, Sintanur, Ciliwung, Ciherang, IR42, Cibogo, Cisadane, Inpari 32, dan Inpari 33.

Uji ketahanan padi dapat dilakukan dengan menilai kemampuan hama untuk menghasilkan senyawa tertentu, misalnya embun madu (honeydew) yang dihasilkan WBC. Jika dalam pengujian ditemukan banyak embun madu pada tanaman yang diuji, berarti tanaman tersebut rentan terhadap WBC. Ketahanan suatu varietas padi terhadap WBC dapat dinilai dari jumlah embun madu yang diekskresikan. Embun madu yang di ekskresikan merupakan hasil cairan yang dihisap WBC dari tanaman padi (Panda \& Kush, 1995).

Air yang telah diserap ke dalam jaringan tanaman berperan sebagai bahan baku fotosintesis, pelarut dan media pengangkut hara mineral yang telah masuk ke dalam akar menuju sel-sel jaringan, medium bagi berlangsungnya reaksi-reaksi metabolisme, dan senyawa utama pembentuk protoplasma (Lehninger, 1982). Serangan WBC mampu menghambat proses terjadinya penyebaran hasil fotosintesis berupa sukrosa ke seluruh bagian tanaman, sehingga menyebabkan tanaman padi menjadi kering dan hampa.

\section{BAHAN DAN METODE}

Percobaan dilaksanakan di rumah kaca Balai Besar Peramalan Organisme Pengganggu Tumbuhan (BBPOPT) Jalan Raya Kaliasin Tromol Pos 1 Jatisari, Karawang, Jawa Barat. Ketinggian tempat 26-50 m dpl dengan temperatur udara ratarata $27,63^{\circ} \mathrm{C}$. Waktu penelitian dilakukan pada bulan Februari-Juni 2017. Varietas padi yang digunakan dalam penelitian ini yaitu Inpari 33, Pelita, Inpari 32, Inpari 13, IR42, Sintanur, Ciherang, Ciliwung, Cisadane, Cibogo. Sementara serangga WBC yang digunakan merupakan WBC betina bunting dan diambil dari koloni Karawang generasi ketiga. 


\section{Persiapan Tanaman Padi yang di Uji}

Varietas padi dengan jumlah 10 varietas yang akan diuji direndam dalam air selama 24 jam. Setelah itu benih diangkat dan diperam selama 48 jam sampai berkecambah. Benih yang telah berkecambah disemai pada pot tanah. Setelah umur 1 minggu bibit padi dipilih dan dicabut untuk dipindahtanamkan ke dalam gelas plastik yang berisi tanah lumpur dan diberi pupuk lengkap. Tiap-tiap varietas tanaman padi ditanam pada gelas plastik dan setiap gelas berisi 1 batang bibit padi. Setelah umur 35-40 hari sudah cukup untuk digunakan dalam pengujian.

\section{Pemeliharaan Wereng Batang Coklat}

Serangga wereng batang coklat dikumpulkan dari lapangan dengan menggunakan aspirator dan dipelihara dirumah kaca pada varietas Pelita yang tidak memiliki gen ketahanan terhadap WBC. Selama pemeliharaan WBC di rumah kaca harus terhindar dari predator (terutama semut dan laba-laba). Cara lain dalam penyediaan serangga uji dapat dilakukan dengan pengambilan WBC betina bunting di sawah, kemudian diinvestasikan pada tanaman padi varietas Pelita atau varietas asal hidupnya di lapangan selama 2 hari. Kemudian semua wereng coklat betina dikeluarkan dari kurungan dan tanaman dipelihara sampai keluar nimfa wereng batang coklat. Selanjutnya nimfa wereng batang coklat dipindahkan ke dalam kurungan pemeliharaan sampai dewasa. Pemeliharaan wereng batang coklat dilakukan sampai generasi yang ke tiga

\section{Pengujian Embun Madu (Honeydew Test)}

Uji sekresi embun madu dilakukan untuk mengetahui reaksi varietas pembeda terhadap WBC, yaitu berdasarkan banyaknya jumlah sekresi yang dihasilkan berupa embun madu. Banyaknya embun madu yang dihasilkan diamati melalui kertas indikator (Pathak \& Heinrichs, 1982 dalam Baco, 1984). Pelaksanaan uji sekresi embun madu adalah sebagai berikut (Pathak \& Heinrichs, 1982 dalam Baco, 1984 ; Heinrichs dkk., 1985 dalam Hariastuti, 2011): tanaman padi umur 35 hari yang ditanam dalam gelas plastik dibersihkan, kemudian bagian permukaan gelas plastik ditutup dengan kertas saring berukuran diameter $9 \mathrm{~mm}$ untuk menampung uap air. Kertas saring dilubangi bagian tengahnya untuk melewatkan batang tanaman padi. Kemudian lempengan mika yang juga dilubangi bagian tengahnya disimpan diatas permukaan kertas saring. Batang tanaman padi dimasukkan melewati mika dengan memasukkan ujung daun tanaman padi melalui lubang pada mika. Lubang kemudian dirapatkan dengan parafilm. Kertas saring yang telah diberi perlakuan bromocressol green $(2 \mathrm{mg} / \mathrm{ml}$ etanol) disimpan di atasnya secara perlahan menggunakan pinset. Gelas yang berisi satu tanaman padi berumur 35 HST kemudian diinokulasi dengan lima WBC betina dewasa. Eksresi dari kelima wereng batang coklat ditampung pada selembar kertas, diamati pada 12, 24 dan 48 jam keadaan WBC yang mati. Kertas indikator segera diambil kemudian dinilai berdasarkan luas bercak eksresi WBC pada kertas. Selanjutnya tanaman di pindahkan ke ember dengan diameter $30 \mathrm{~cm}$ dan dipelihara di rumah kaca untuk diamati sampai menghasilkan malai (panen).

\section{Rancangan Respons}

Adapun yang menjadi parameter pengamatan dalam penelitian ini yaitu luas bercak embun madu, mortalitas wereng batang coklat, intensitas serangan, tingkat kerusakan tanaman, dan bobot hasil. Pengukuran luas bercak embun madu dilakukan dengan menjiplak kertas indikator asam basa yang terdapat bercak embun madu pada milimeter blok. Pengukuran dilakukan 48 jam setelah perlakuan (35 HST) yaitu pada saat padi berumur $37 \mathrm{HST}$.

Pengamatan mortalitas wereng batang coklat dilakukan setelah wereng batang coklat diinvestasikan pada tanaman padi berumur 35 HST. Pengamatan dilakukan selama 48 jam, yaitu pada 24 jam dan 48 jam setelah perlakuan, dengan persamaan sebagai berikut:

Mortalitas $=\frac{\text { jumlahindividu yang mati }}{\text { jumlah individu } \text { yang diuji }} \times 100 \%$

Tabel 1. Kriteria skala mortalitas wereng batang coklat.

\begin{tabular}{cc}
\hline Tingkat mortalitas & Kriteria mortalitas \\
\hline 0 & - \\
$>25 \%$ & Rendah \\
$<26 \%-50 \%$ & Sedang \\
$<51 \%-75 \%$ & Tinggi \\
$<76 \%$ & Sangat tinggi \\
\hline
\end{tabular}

Sumber : Heryanto et al. (2006)

Pengamatan intensitas serangan dilakukan setelah 7 hari perlakuan yaitu pada saat padi berumur 42 HST dengan menghitung jumlah tanaman yang terserang wereng batang coklat 
ditandai dengan batang padi berwarna kuning kecokatan sampai mengalami busuk batang. Rumus yang digunakan untuk menghitung intensitas serangan adalah:

$$
\mathrm{I}=\frac{\sum(n \times v)}{N \times V} \times 100 \%
$$

Keterangan :

$$
\begin{aligned}
\mathrm{I} & =\text { intensitas serangan }(\%) \\
\mathrm{n} & =\text { jumlah tanaman dengan skala kerusakan } \\
& \text { yang sama } \\
\mathrm{V} & =\text { nilai skala } \\
\mathrm{N} & =\text { jumlah tanaman yang diamati } \\
\mathrm{V} & =\text { nilai skor tertinggi }
\end{aligned}
$$

Tabel 2. Skala kerusakan akibat serangan WBC.

\begin{tabular}{cl}
\hline $\begin{array}{c}\text { Skor } \\
\text { kerusakan }\end{array}$ & \multicolumn{1}{c}{ Gejala kerusakan } \\
\hline 0 & $\begin{array}{l}\text { Tidak ada gejala } \\
\text { Sebagian daun pertama menguning, } \\
\text { tidak terjadi kelayuan, terdapat } \\
\text { WBC, sedikit embun jelaga } \\
\text { Sebagian daun pertama dan kedua } \\
\text { menguning, agak layu, ditemukan } \\
\text { banyak embun jelaga } \\
\text { Sebagian besar daun menguning, } \\
\text { daun bawah layu, tanaman kerdil, } \\
\text { embun jelaga banyak } \\
\text { Daun mengeriting dan hampir semua } \\
7\end{array} \quad \begin{array}{l}\text { layu, tanaman sangat kerdil } \\
\text { Layu sempurna, tanaman mati }\end{array}$
\end{tabular}

(Sumber : Saepul, 2014)

Pengamatan tingkat kerusakan tanaman padi dilakukan setelah 7 hari perlakuan yaitu pada saat tanaman berumur 42 HST dengan menghitung jumlah daun yang rusak. Tingkat serangan hama diklasifikasikan berdasarkan tingkat serangannya pada tumbuhan (Tabel 3). Rumus yang digunakan untuk menghitung tingkat kerusakan tanaman yaitu:

Keterangan :

$$
\mathrm{I}=a / b \times 100 \%
$$

$\mathrm{I}=$ kerusakan tanaman

$\mathrm{a}=$ jumlah daun yang terserang

$\mathrm{b}=$ jumlah seluruh daun

Pengamatan bobot hasil di lakukan dengan menimbang berat butir malai masing-masing varietas padi. Pengukuran bobot hasil butir malai padi sesuai dengan umur panen setiap varietas, yaitu varietas Pelita dipanen saat berumur 135 HST, varietas Inpari 32 dipanen saat berumur $120 \mathrm{HST}$, varietas Inpari 33 dipanen saat berumur $107 \mathrm{HST}$, varietas Ciliwung dipanen saat berumur 117 HST, varietas Ciherang dipanen saat berumur 116 HST, varietas Cisadane dipanen saat berumur 135 HST, varietas Cibogo dipanen saat berumur 115 HST, varietas Inpari 13 dipanen saat berumur 103 HST, varietasSsintanur dipanen saat berumur $120 \mathrm{HST}$, dan varietas IR42 dipanen saat berumur 135 HST. Pengukuran bobot hasil bulir malai dinyatakan dalam satuan gram dan dihitung masing-masing ulangan.

Tabel 3. Kategori tingkat serangan WBC

\begin{tabular}{cc}
\hline Intensitas serangan & Kategori \\
\hline $0 \%$ & Tidak terserang \\
$<25 \%$ & Intensitas sangat \\
$>26-50 \%$ & ringan \\
$>51-75 \%$ & Intensitas ringan \\
$76 \%$ & Intensitas sedang \\
\hline
\end{tabular}

Sumber : Direktorat Perlindungan Tanaman Pangan, 2008.

\section{HASIL DAN PEMBAHASAN}

\section{Luas Bercak Embun Madu}

Hasil analisis ragam luas bercak embun madu pada setiap varietas padi dapat dilihat pada Tabel 4. Terdapat variasi luas bercak embun madu pada masing-masing varietas padi. Hal ini menunjukan adanya perbedaan ketahanan antara varietas padi yang diuji terhadap serangan wereng batang coklat koloni Karawang.

Ketahanan suatu varietas padi terhadap WBC dapat dinilai dari luas bercak embun madu yang diekskresikan (Panda \& Khush, 1995). Bercak embun madu yang diekskresikan oleh WBC pada varietas Pelita paling luas, dan terendah terjadi pada varietas Inpari 33. Hal ini menunjukkan bahwa varietas Pelita paling rentan karena tidak adanya gen ketahanan (Baehaki \& Mejaya, 2014), sementara varietas Inpari 33 memiliki gen ketahanan. Paguia et al. (1980) menyatakan bahwa perbedaan jumlah embun madu yang diekskresikan dikaitkan dengan perbedaan jumlah nutrisi yang dimakan oleh WBC pada varietas tahan dan varietas rentan. Semakin banyak cairan sukrosa yang dihisap maka WBC akan mengeluarkan eksresi berupa embun madu lebih banyak.

Perbedaan ketahanan varietas padi terhadap wereng batang coklat diduga karena adanya mekanisme antibiosis yang dapat menghambat 
pertumbuhan dan perkembangan serangga hama. Hal ini sejalan dengan pendapat Astuti (2009) yang menyatakan bahwa ketahanan tanaman dapat berupa antibiosis yaitu tanaman menghasilkan toksin yang dapat membunuh atau menghambat pertumbuhan hama. Antibiosis ialah suatu sifat tanaman yang berpengaruh buruk terhadap kehidupan serangga.

Tabel 4. Rata-rata luas bercak embun madu $\left(\mathrm{mm}^{2}\right)$ yang dihasilkan oleh WBC ( $N$. lugens) pada 48 jam setelah perlakuan.

\begin{tabular}{lrl}
\hline Varietas & Rata-rata luas bercak $\left(\mathrm{mm}^{2}\right)$ \\
\hline Pelita & $2957,0 \mathrm{~d}$ \\
Inpari 33 & $1307,2 \quad \mathrm{a}$ \\
Inpari 13 & $1490,8 \mathrm{ab}$ \\
IR42 & $1804,6 \mathrm{bc}$ \\
Sintanur & 1555,0 abc \\
Ciherang & 1310,0 a \\
Ciliwung & 1467,0 ab \\
Cisadane & 1959,2 c \\
Cibogo & 1355,4 ab \\
Inpari 32 & 1611,0 abc \\
\hline Keterangan : Angka rata-rata yang diikuti dengan huruf \\
\multicolumn{5}{c}{ yang sama menunjukan tidak berbeda } \\
& nyata dengan uji Duncan pada taraf \\
pengujian 5\%.
\end{tabular}

Antibiosis disebabkan oleh adanya zat kimia yang bersifat sebagai zat penolak racun, adanya nutrisi tertentu yang tidak tersedia bagi serangga serta adanya perbedaan nutrisi dalam kuantitasnya. Antiobiosis yang terdapat pada tanaman padi yaitu berupa asam oksalat.

Asam oksalat diketahui mengganggu proses makan wereng batang coklat pada tanaman padi, dengan cara menghambat proses pengisapan pada floem. Asam oksalat merupakan faktor penting yang mengontrol ketahanan tanaman padi terhadap WBC. Zat ini mempengaruhi metabolisme dan sintesis protein dalam tubuh serangga. Oksalat dapat berbentuk oksalat terlarut (soluble oxalte) dan oksalat tidak terlarut (insoluble oxalate). Oksalat terlarut dapat berupa asam oksalat dan oksalat tidak terlarut dapat berupa kristal kalsium oksalat (Franchesi \& Nakata, 2005). Pada tanaman angiospermae, oksalat dalam bentuk asam oksalat maupun kristal kalsium oksalat, disimpan di dalam vakuola sel (Muji, 2013).

Perbedaan ketahanan pada beberapa varietas uji dapat disebabkan adanya perbedaan tingkat asam oksalat yang terkandung pada masing- masing varietas tersebut. Tentu saja hal itu perlu dilakukan penelitian lebih lanjut mengenai tingkat kandungan asam oksalat yang terdapat pada masingmasing varietas padi tersebut.

\section{Mortalitas Wereng Batang Coklat}

Hasil analisis ragam terhadap pengaruh pemberian WBC pada 10 varietas padi umur 37 HST menunjukan tidak adanya pengaruh. Tabel 5 menunjukkan bahwa, tingkat mortalitas dari WBC pada setiap varietas padi berbeda-beda. Dimana tingkat mortalitas tertinggi terdapat pada WBC yang diinokulasi pada varietas Inpari 33 dan terendah pada varietas Pelita. Semakin tinggi tingkat mortalitas setelah inokulasi WBC selama 48 jam pada varietas yang sama maka semakin rendah luas bercak embun madu. Sebaliknya semakin rendah tingkat mortalitas maka semakin luas bercak embun madu. Tingkat mortalitas yang tinggi dan luas bercak embun madu yang rendah mengindikasikan varietas tersebut tahan terhadap serangan wereng batang coklat.

Pengamatan mortalitas dilakukan selama 48 jam yaitu pada 12 jam, 24 jam, dan 48 jam setelah perlakuan. WBC yang mati pada waktu 12 jam setelah perlakuan diganti dengan wereng lain. WBC yang mati pada 12 jam diasumsikan mati tanpa ada pengaruh gen ketahanan varietas tanaman padi. WBC yang mati pada 12 jam setelah perlakuan dapat diakibatkan karena teknik menghisap dan investasi WBC dengan aspirator yang terlalu kencang, sehingga mengakibatkan wereng batang coklat mati.

Tabel 5. Rata-rata mortalitas wereng batang coklat (Nilaparvata lugens Stall) 48 jam setelah perlakuan.

\begin{tabular}{lcl}
\hline Varietas & Jumlah Mortalitas \\
\hline Pelita & 14 a \\
Inpari 33 & 19 a \\
Inpari 13 & 17 a \\
IR42 & 17 a \\
Sintanur & 15 a \\
Ciherang & 18 a \\
Ciliwung & 15 a \\
Cisadane & 17 a \\
Cibogo & 15 a \\
Inpari 32 & 16 a \\
\hline
\end{tabular}

Keterangan: Angka-angka yang diikuti huruf yang sama menunjukkan tidak berbeda nyata menurut uji Duncan pada taraf pengujian 5\%.

Setiap varietas yang diuji menunjukan hasil yang berbeda terhadap tingkat mortalitas wereng 
batang coklat. Nilai kriteria mortalitas pada penelitian ini bervariasi dari sedang sampai tinggi, mortalitas yang tinggi dengan tingkat mortalitas > $50 \%$, terdapat pada varietas Inpari 33 yaitu $72 \%$.

Ketahanan varietas padi ditinjau dari segi morfologi, varietas tahan dan agak tahan memiliki batang yang keras dan daun yang kasar. Hal yang demikian pada umumnya kurang disukai oleh WBC. Batang yang keras dan daun yang kasar diduga dapat menyulitkan WBC saat menusukkan alat pada mulutnya untuk mengisap cairan tanaman dan dapat menyebabkan kematian pada nimfa karena tidak dapat menyerap cairan di dalam floem (Qomaroodin, 2006).

Mekanisme ketahanan antisenosis yang lebih tinggi terdapat pada varietas tahan (Inpari 33). Menurut Cunningham et al. (2001), kesesuaian WBC bertahan pada varietas padi tergantung pada beberapa faktor seperti kualitas nutrisi, zat kimia pertahanan kimia tumbuhan dan lingkungan mikro. Mekanisme ketahanan antixenosis merupakan mekanisme ketahanan oleh tanaman untuk mereduksi kolonisasi serangga. Umumnya serangga berorientasi sendiri terhadap tanaman untuk makan, meletakkan telur dan tempat berlindung. Sifat antixenosis tanaman tidak memberikan kesempatan kepada serangga untuk berkoloni. Tanaman yang memperlihatkan ketahanan dengan antikenosis mampu mengurangi jumlah awal kolonisasi pada satu musim.

Antixenosis merupakan mekanisme
ketahanan tanaman untuk menjerakan atau mereduksi koloni serangga. Sementara pada mekanisme antibiosis, ketahanan bekerja setelah serangga berkoloni dan telah memakan cairan tanaman. Antibiosis menurunkan populasi secara kumulatif dengan menurunkan daya reproduksi, lamanya waktu reproduksi, dan kematian nimfa. Pada tanaman yang toleran, secara genetik tanaman mampu mentoleransi hama dengan kehilangan hasil minimal (Iswanto, 2016).

Data proteomik (protein genom) menunjukkan bahwa mekanisme makan WBC disertai dengan bermacam tekanan seperti melukai, stres oksidatif, patogenesis dan sifat herbivora serangga. Saat seranggga makan, pengembangan pertahanan dasar yang kuat terjadi pada varietas rentan dibandingkan dengan varietas tahan. Ekspresi protein jasmonic acid (JA) sintesis, protein stress oksidatif, Gns1 (glucanase 1), protein kinase dan clathrin dengan rantai protein yang berat meningkat pada kedua varietas rentan maupun tahan, tetapi tingkat ekspresi yang lebih tinggi terlihat pada galur rentan setelah diberi perlakuan WBC (Wei et al., 2009).

Senyawa metabolit sekunder yang bersifat racun berperan penting pada ketahanan varietas, seperti asam oksalat pada padi yang menghambat aktifitas makan WBC (Iswanto, 2016). Senyawa asam oksalat mampu menurunkan kemampuan makan nimfa dan peletakan telur WBC. Senyawa asam oksalat mengganggu perilaku makan WBC dengan cara meningkatkan durasi penusukan stilet dan menghambat penghisapan cairan. Senyawa asam oksalat terdapat pada batang, daun dan sekam padi. Asam oksalat senyawa yang berfungsi sebagai penghambat pengisapan cairan floem oleh WBC, sedangkan asam amino asparagin dan sukrosa sebagi stimulant makan WBC. Jika kandungan asam oksalat tinggi maka WBC tidak tertarik untuk meletakkan telur pada batang tanaman padi dan asam oksalat yang tinggi akan mempunyai ketahanan terhadap WBC. Ketahanan varietas padi terhadap WBC merupakan hasil kerja senyawa metabolit. Perakitan varietas tahan menggunakan senyawa metabolit sebagai penanda dapat menjadi alternatif dalam mendeteksi ketahanan varietas padi hasil persilangan dalam jumlah banyak dengan cara mudah dan tepat.

\section{Intensitas Serangan WBC pada Berbagai Varietas Padi}

Hasil pengamatan intensitas serangan pada tanaman padi berbeda-beda pada setiap varietasnya. Intensitas serangan tertinggi yaitu pada varietas Inpari 32, Cisadane dan Pelita sebesar 80\% (gejala sangat parah), sedangkan intensitas terendah yaitu pada varietas Inpari 33 sebesar 20\% (serangan ringan). Hal ini menunjukan terjadinya pengaruh serangan WBC terhadap pertumbuhan tanaman padi. Intensitas serangan dihitung pada tanaman padi yang berumur 42 HST, yaitu 7 hari setelah diaplikasikan WBC.

Kerusakan yang ditimbulkan WBC adalah tanaman padi mengering karena WBC menghisap cairan dalam jaringan pengangkut (batang) tanaman padi. Gejala serangan WBC pada rumpun dapat terlihat dari daun-daun yang menguning, kemudian tanaman mengering dengan cepat (seperti terbakar).

Tingginya intensitas serangan WBC banyak ditanam oleh petani sehingga varietas tersebut termasuk selalu ada dipertanaman setiap musim tanam pada skala luas sehingga menyediakan makanan dan habitat yang sesuai dan terus menerus bagi WBC. Konsekuensi introduksi padi varietas unggul ialah munculnya kecenderungan petani untuk menanam varietas tersebut, sehingga dalam 
suatu kawasan persawahan hanya ada satu atau dua varietas yang ditanam sehingga keragaman genetik dikawasan itu sangat sempit. Selain itu ketahanan suatu varietas unggul umumnya dikendalikan oleh suatu gen tahan yang menghasilkan ketahanan vertikal atau ketahanan spesifik. Sifat tahan seperti ini memiliki tekanan yang tinggi terhadap serangga hama namun mempunyai dorongan yang kuat pada hama untuk mengadakan seleksi diri membentuk populasi yang mampu menghancurkan varietas yang semula tahan (Suparyono \& Setyono, 1997 dalam Rugaya \& Dahyar, 2013).

\section{Tingkat Kerusakan Beberapa Varietas Padi oleh WBC}

Hasil pengamatan setelah 7 hari aplikasi WBC tingkat kerusakan pada tanaman padi berbedabeda. Tingkat kerusakan yang paling tinggi yaitu pada varietas Cisadane sebesar 50\%. Sedangkan tingkat kerusakan paling rendah pada varietas Inpari 33 sebesar 13,33\% (data tidak ditampilkan).

Kerusakan tanaman dapat menyebabkan kerugian secara ekonomis. Kebanyakan hama yang menyebabkan kerusakan pada tanaman adalah dari kelompok serangga. Keberadaan hama WBC sangat dirisaukan, karena kerusakan yang ditimbulkan oleh serangan WBC bisa menyebabkan kualitas dan kuantitas panen mengalami penurunan. Hal tersebut mengakibatkan kerugian secara ekonomi.

Serangan yang ditimbulkan oleh hama WBC warna daun tanaman padi menjadi berwarna kuning, jika tetap dibiarkan akan berubah menjadi berwarna coklat, dan akhirnya seluruh tanaman padi akan mengering (hopperburn). Kondisi lingkungan yang sesuai selama pertumbuhan akan merangsang tanaman untuk berbunga dan menghasilkan benih. Kebanyakan spesies tidak akan memasuki masa reproduktif jika pertumbuhan vegetatifnya belum selesai dan belum mencapai tahapan yang matang untuk berbunga, sehubungan dengan ini terdapat dua rangsangan yang menyebabkan perubahan itu terjadi, yaitu suhu dan panjang hari (Mugnisjah \& Setiawan, 1995).

Selain itu, terjadinya peningkatan luas serangan WBC dipicu oleh penanaman varietas rentan secara rutin oleh petani tanpa adanya pergiliran varietas. Faktor iklim, khususnya suhu udara memiliki pengaruh secara langsung terhadap pertumbuhan dan perkembangan populasi hama,seperti: siklus hidupnya menjadi lebih singkat sehingga dapat menyebabkan peningkatan populasi dengan demikian tingkat kerusakan yang ditimbulkan menjadi semakin besar.

\section{Bobot Hasil Beberapa Varietas Padi yang Terserang WBC}

Hasil analisis ragam bobot hasil 10 varietas padi menunjukan hasil tidak ada pengaruh nyata dari berbagai jenis varietas terhadap hasil panen (Tabel 6). Andoko (2002) menyatakan bahwa secara umum padi dikatakan sudah siap panen bila butir gabah yang menguning sudah mencapai sekitar $80 \%$ dan tangkainya sudah merunduk. Untuk lebih memastikan padi sudah siap panen adalah dengan cara menekan butir gabah. Bila bulirnya sudah keras berisi maka saat itu paling tepat untuk dipanen.

Bobot butir malai diamati dengan cara menimbang semua hasil butir malai per rumpun saat panen yaitu pada fase generatif. Bobot hasil paling tinggi yaitu pada varietas Cisadane meskipun secara statistik tidak berbeda nyata dengan varietas lainnya. Varietas Cisadane merupakan varietas padi yang memiliki tingkat kerontokan paling rendah dibandingkan varietas lainnya, sehingga varietas Cisadane memiliki bobot hasil paling tinggi dibandingkan varietas lainnya.

Tabel 6. Rata-rata bobot hasil gabah (g) pada masing-masing varietas padi.

\begin{tabular}{lrl}
\hline Varietas & Rata-rata Bobot Hasil $(\mathrm{g})$ \\
\hline Pelita & 23,316 a \\
Inpari 33 & $15,576 \quad$ a \\
Inpari 13 & $22,854 \quad$ a \\
IR42 & $24,524 \quad$ a \\
Sintanur & $25,042 \quad$ a \\
Ciherang & 22,056 a \\
Ciliwung & 17,222 a \\
Cisadane & 25,300 a \\
Cibogo & $19,762 \quad$ a \\
Inpari 32 & 21,048 a \\
\hline
\end{tabular}

Keterangan: Angka-angka yang diikuti huruf yang sama menunjukkan tidak berbeda nyata menurut uji Duncan pada taraf pengujian 5\%.

Rozakurniati (2010) menyatakan bahwa Cisadane sulit dirontokkan. Hal ini mengindikasikan bahwa batang Cisadane relatif lebih kuat. Ditinjau dari segi morfologi, varietas tahan dan agak tahan memiliki batang yang keras dan permukaan daun yang agak kasar. Hal yang demikian pada umumnya kurangdisukai oleh WBC. Batang yang keras dan daun yang kasar diduga dapat menyulitkan WBC saat menusukkan alat pada mulutnya untuk menghisap cairan tanaman dan dapat pula menyebabkan kematian pada nimfa karena tidak dapat makan. 
Produksi padi menurun dengan semakin tinggi tingkat serangan WBC, semakin cepat terserang WBC dan semakin tinggi populasi WBC.Virus yang dibawa oleh WBC dapat masuk dengan mudah ke dalam jaringan kutikula yang impermiabel yang menutup epidermis tanaman dan secara langsung masuk ke dalam jaringan atau sitoplasma (Zhang et al., 2010). Serangan yang berat dapat mengakibatkan puso (hopperburn) dan mengagalkan panen seperti yang terjadi pada penelitian ini pada varietas Inpari 33 dan Ciliwung.

\section{SIMPULAN}

1. Terdapat pengaruh ketahanan dan hasil tanaman padi terhadap serangan wereng batang coklat (WBC)

2. Varietas Inpari 33 merupakan varietas paling tahan di lihat berdasarkan parameter luas bercak embun madu, mortalitas wereng batang coklat, intensitas serangan, dan tingkat kerusakan tanaman.

\section{DAFTAR PUSTAKA}

Andoko, A. 2002. Budidaya Padi Secara Organik. Cetakan-I. Penebar Swadaya, Jakarta. BALITBANG, 1989. Padi. Edisi ke-2. Pusat Penelitian dan Pengembangan Tanaman Pangan. Bogor.

Baehaki, SE. 1986. Komplikasi Serangan Wereng Batang Coklat dan Wereng Hijau di Pertanaman. Purwokerto: HIMASITA Universitas Jenderal Soedirman.

Baehaki, SE. 2012. Perubahan pengendalian hama terpadu (PHT) konvensional menuju PHT biointensif. Pros. Sem. Nas. Inovasi Teknologi Berbasis Ketahanan Pangan Berkelanjutan. Puslitbangtan. Buku 2. p. 203-214.

Baehaki, SE dan IMJ Mejaya. 2014. Wereng cokelat sebagai hama global bernilai ekonomi tinggi dan strategi pengendaliannya. IPTEK Tanaman Pangan 9 (1): 1-12.

Cunningham, JP, SA West, and MP Zalucki. 2001. Host selection in phytopagous insects a new explanation for learning in adults. Oikos 93(3): 537-543.

Direktorat Perlindungan tanaman. 2008. Pedoman Pengamatan dan Pelaporan Perlindungan tanaman Pangan. Jakarta. Hal 39
Franchesi, VR, and PA Nakata. 2005. Calcium oxalate in plants: formation and functions. Annual Review of Plant Biology 56:41-71.

Hariastuti, M. 2011. Pengujian ketahanan beberapa kultivar padi beras merah dan hitam terhadap wereng batang coklat Nilaparvata lugens Stall (Homoptera : Delphacidae). Skripsi. Universitas Andalas. Padang.

Kastanja, AY. 2011. Kajian penerapan teknik budidaya padi gogo varietas lokal. Jurnal Agroforestri 6(2): 121-128.

Muji, A. S. 2013. Distribution of Calcium Oxalate Cristal, Reduction of Oxalates, and the Effect of Cultivation Method on Its Formation in Some Vegetables. Universitas Nusantara PGRI Kediri

Ningsih, NF, E Ratnasari, dan U Faizah. 2016. Pengaruh ekstrak daun kumis kucing (Orthosiphon aristatus) terhadap mortalitas hama wereng coklat (Nilaparvata lugens). LenteraBio 5(1): 14-19.

Paguia, P, MD Pathak, and EA Heinrichs. 1980. Honeydew excretion measurement techniques for determining differential feeding activity of biotypes of Nilaparvata lugens on rice varieties. J. Econ. Entomol. 73: 35-40.

Panda, N, dan GS Kush. 1995. Host plant resistance to insects. Philippines: CAB International in association with the International Rice Research Institute.

Qomaroodin. 2006. Teknik Uji Ketahanan Varietas/Galur Harapan Padi Pasang Surut terhadap Wereng Batang Coklat (Nilaparvata Lugens Stall). Buletin Teknik 11(2).

Setyorini, SD, Shoahuddin dan A Sulistyo. 2013. Existence of brown planthopper's natural enemies on some rice varieties using different cultivation techniques. J ournal of Agronomy Research 2(5):8-17.

Sjakoer, NAA. 2010. Mortalitas Hama Wereng Punggung Putih Setelah dimangsa oleh Serangga Predator (Pengamatan Visualisasi di Green House). Jurnal El-Hayah 1(2) : 3539.

Sutrisno. 2014. Resistensi wereng batang coklat terhadap insektisida di Indonesia. AgroBiogen. 10(3): 115-124.

Syahrawati, M. Busniah dan N Nelly. 2010. Sosialisasi Teknik Konservasi Musuh Alami Wereng Coklat (Nilaparvata lugens) pada Petani Perempuan. Lembaga Pengabdian 
kepada Masyarakat Universitas Andalas. Zhang F, H Guo, and H Zheng. 2010. Massively Padang.

Wei Z, W Hu1, Q Lin, X Cheng, M Tong, L Zhu, R parallel pyrosequencing-based Chen and $\mathrm{G}$ He. 2009. Understanding rice transcriptome analyses of small brown planthopper (Laodelphax striatellus), a plant resistance to the Brown Planthopper (Nilaparvata lugens). Proteomic Approach. vector insect transmitting rice stripe virus 9: 2798-2808. (RSV). Genomics11: 1-13. 